Vol. 17 (2008): 240-251.

\title{
Comparison of energy and greenhouse gas balances of biogas with other transport biofuel options based on domestic agricultural biomass in Finland
}

\author{
Hanna L. Tuomisto ${ }^{1 *}$ and Juha Helenius \\ Department of Applied Biology, PO Box 27 FI-00014 University of Helsinki, Finland, \\ ${ }^{1}$ Current address: Wildlife Conservation Research Unit, University of Oxford, Tubney, OX13 5QL, UK \\ *e-mail: hanna.tuomisto@zoo.ox.ac.uk
}

Biofuels have been promoted as a way to reduce greenhouse gas (GHG) emissions, but it is questionable whether they indeed do so. The study compared energy and GHG balances of transport biofuels produced in Finnish conditions. Energy and GHG balances were calculated from a life cycle perspective for biogas when timothy-clover and reed canary grass silages and green manure of an organic farm were used as a raw material. The results were compared with published data on barley-based ethanol, rape methyl ester (biodiesel) and biowaste-based biogas. The energy input for biogas was $22-37 \%$ of the output depending on the raw material. The GHG emissions from field-based biogas were $21-36 \%$ of emissions from fossil-based fuels. The largest energy input was used in the processing of the biofuels while most of the greenhouse gases were emitted during farming. The GHG emissions of the field-based biogas were emitted mainly from fuels of farming machinery, nitrous oxide $\left(\mathrm{N}_{2} \mathrm{O}\right)$ emissions of the soil and the production of ensiling additives. The energy efficiency was most sensitive to the methane yield, and GHG emissions to the $\mathrm{N}_{2} \mathrm{O}$ emissions. Biogas had clearly lower energy input and GHG emissions per unit energy output than domestic barley-based ethanol and biodiesel.

Key-words: biogas, biofuels, bioenergy, life cycle assessment, greenhouse gas emissions, energy balance, environmental impacts 
Vol. 17 (2008): 240-251.

\section{Introduction}

Climate change, limited oil resources and political goals for increased self-sufficiency of fuels are the main factors affecting the development of biofuels. The European Union set a target that biofuels should replace $5.75 \%$ of fossil fuels in the transport sector by 2010 (Directive 2003/30 EC). However, not all biofuels are equal in terms of energy efficiency and greenhouse gas (GHG) emissions.

Mäkinen et al. (2006) demonstrated that GHG emissions of Finnish rape methyl ester (biodiesel) and barley-based ethanol are even greater than those of fossil diesel and petrol when the emissions of the whole life cycle were estimated. They found that second generation biofuels, produced using forest biomass or reed canary grass as raw materials, reduced GHG emissions by up to $70-80 \%$ compared to fossil fuels. However, they did not include biogas in their study, although it has frequently been suggested elsewhere as an environmentally efficient option for energy production in agriculture (e.g., Jungmeier and Spitzer 2001).

The production of biogas by anaerobic digestion may provide multiple environmental benefits. In addition to producing energy from renewable resources, it can contribute to recycling of nutrients, and reduce environmental impacts of fertiliser use and manure treatment. In the process, nutrient losses are minimal (e.g., Börjesson and Berglund 2007). Another benefit of biogas production is that wide ranged organic materials, including manure, crops, weeds, sewage sludge and industrial and municipal biowaste, can be used as raw material.

Biogas production can also improve the economy and efficiency of organic crop farms. Organic farms use around $25 \%$ of their arable area for green manuring. In current practice, the green manure crops are ploughed into the soil, and the energy of the biomass is lost. Especially in organic arable farms, which lack of source of animal manure, a biogas reactor could be a surrogate for the cattle, "milking" energy and recycling nutrients harvested by the green-manure crops. The digestate, i.e., the residue of biogas production, could then be used as an organic fertiliser, in a form comparable to slur- ry. In addition, nutrient use efficiency for the crop plants may be improved, because the nitrogen in the digestate is in ammonium $\left(\mathrm{NH}_{4}^{+}\right)$form instead of in the original plant material, and more readily mineralised for the crop (Lehtomäki 2006).

The aim of this article is to fill the gap in the knowledge about the comparative advantage of biogas as an option for Finnish agricultural biofuel production, especially concerning energy and GHG balances of biogas produced in Finnish conditions.

\section{Material and methods}

Energy and GHG emissions of field-based biogas were assessed using life cycle perspective in four different alternatives:

1. Organic Ley $(\mathrm{OL})$ : an organic crop farming system where a timothy-clover green manuring crop is harvested three times a year as silage and used as a raw material for biogas. Digestate from biogas production is used as a fertiliser. The timothy-clover ley is a part of four year crop rotation: 1) rye, 2) green pea, 3) spring cereal with ley seed and 4) timothy-clover ley. The grass ley is ploughed in the autumn. From the production of organic ley, only emissions and inputs of the silage harvesting are allocated to the biogas. The logic here is that the green manuring crops in organic crop farms are produced anyway, but they are normally ploughed into the soil. In this model system instead, the ley is harvested and nutrients are simply circulated through the biogas reactor.

2. Bioenergy Ley (BL): Timothy-clover crop is harvested three times a year and renewed every three years including ploughing of the field. Digestate from biogas production is used as a fertiliser for other crops. All inputs and emissions of cultivation are allocated to biogas, and the energy and GHG emissions saved by substituting mineral fertilisers by digestate are subtracted from the burden of biogas. 
Tuomisto, H.L. and Helenius, J. Energy and greenhouse gas balances of biogas

3. Reed canary grass -Organic (RO): Reed canary grass silage is harvested three times a year and renewed every 5 years. Digestate is used as a fertiliser and some extra organic fertilisers (e.g. digestate from food industry or sewage sludge) are used. The impacts of the production of the additional organic fertiliser are not allocated to biogas, because it is assumed that these materials would have been otherwise wasted.

4. Reed canary grass -Mineral (RM): As RO, but mineral fertilisers instead of digestate are used as an additional fertiliser. This option serves comparison of the system with and without use of mineral fertilisers.

For each of the four systems, two reactor options were assessed. In case 1, heat exchangers were not used, and in 2, heat exchangers were used. Heat exchangers use the heat of the digestate to warm the raw material, and thus, reduce the extra energy input required for warming the reactor (Berglund and Börjesson 2006). In farm-scale biogas plants, however, the possibilities to use heat exchangers may be limited, so reactors both with and without heat exchangers were considered in this study.

The functional unit, in which all the inputs were proportioned, was one GJ biogas output per year for transport fuel use. Production of inputs, cultivation, anaerobic digestion, processing of biogas, delivery and use as transport fuel were included within the system boundaries (Fig. 1). Production of machinery and building of the necessary physical infrastructure were excluded from the base calculations, but production and maintenance of machinery has been assessed in the sensitivity analysis by assuming that production and maintenance correspond to $8 \%$ and $20 \%$, respectively, of the energy content in the fuel (Berglund and Börjesson 2006). The use of fuels for machinery, fertilisers and lime include production, transportation and consumption of the fuels. All calculations are based on data from literature. The system boundaries and base data were harmonised with, and can be found in the study of Mäkinen et al. (2006). This allows for comparison of the results with the results of Mäkinen et al. (2006) for biodiesel and barley-based ethanol produced in Finnish conditions.

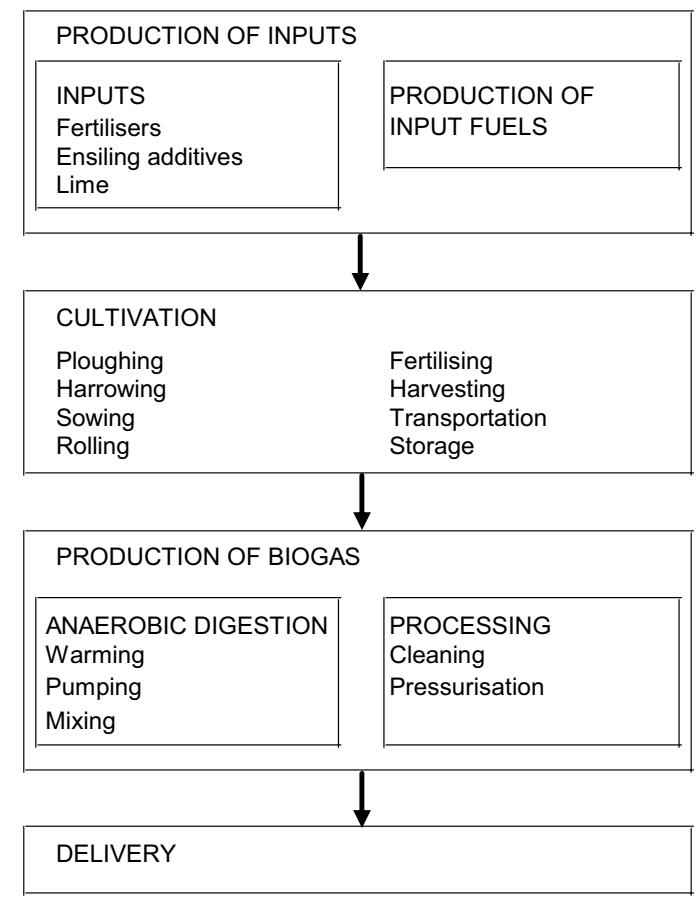

Fig. 1. Boundaries of the studied biogas production system.

It was assumed that prime agricultural land was used. The crop yield of the timothy-clover crop was determined according to official experiments of Agrifood Research Finland (Kangas et al. 2004 and 2006) and adjusted to allow that with harvesting losses the yield was $85 \%$ of the experimental yields, resulting in an estimated dry matter (DM) yield of $6.5 \mathrm{t} \mathrm{ha}^{-1} \mathrm{yr}^{-1}$. For reed canary grass, official results are not available and thus the green yield was determined according to Lehtomäki (2006) as $9.0 \mathrm{t} \mathrm{DM} \mathrm{ha}^{-1} \mathrm{yr}^{-1}$. The emissions of three main greenhouse gases, carbon dioxide $\left(\mathrm{CO}_{2}\right)$, methane $\left(\mathrm{CH}_{4}\right)$ and nitrous oxide $\left(\mathrm{N}_{2} \mathrm{O}\right)$ were assessed using the guide values of IPCC (1996) for GHG warming potentials for 100 years $\left(\mathrm{GWP}_{100}\right)$. The production and distribution of diesel fuel was estimated to represent $16 \%$ of the energy content in the fuel, thus 41.4 MJ of primary energy per litre (Edwards et al. 2003). The indirect energy needed in the production and distribution of electricity has been estimated to 
Vol. 17 (2008): 240-251.

correspond to $10 \%$ of the energy content (Mäkinen et al. 2006). The default value for primary energy demand of electricity was $2.35 \mathrm{kWh}_{\text {prim }} \mathrm{kWh}_{\mathrm{e}}^{-1}$. (Mäkinen et al. 2006). Electricity was assumed to correspond to the average electricity sources in Finland, and thus the GHG emissions of electricity were estimated to be $250 \mathrm{~g} \mathrm{CO}_{2}$-eq $\mathrm{kWh}_{\mathrm{e}}^{-1}$.

RM was the only model system, in which mineral fertilisers were used. The fertiliser amount was $40 \mathrm{~kg}$ nitrogen ha-1 $6 \mathrm{~kg}$ phosphorus ha $\mathrm{h}^{-1}$ and $16 \mathrm{~kg}$ potassium ha-1 ${ }^{-1}$ According to Mäkinen et al. (2006), the production and transportation of that fertiliser consumes energy of $11.9 \mathrm{GJ} \mathrm{t}^{-1}$ and the GHG emissions are $2143 \mathrm{~kg} \mathrm{CO}_{2}$-eq t${ }^{-1}$.

It is estimated that in Finnish conditions the direct and indirect $\mathrm{N}_{2} \mathrm{O}$ emissions from nitrogen fertilisers accounts for $2.55 \%$ (uncertainty $-84 \%$ $-338 \%$ ) of the nitrogen applied (Mäkinen et al. 2006). This emission factor was used regardless of the nitrogen source. It was assumed that the nitrogen fixation in the BL was $128 \mathrm{~kg} \mathrm{ha}^{-1} \mathrm{yr}^{-1}$, and total amount of nitrogen applied for reed canary grass was $200 \mathrm{~kg} \mathrm{ha}^{-1} \mathrm{yr}^{-1}$ in the both models. The amount of lime used was assumed to be $4 \mathrm{t} \mathrm{ha}^{-1}$ every 10 years. The energy required for spreading of lime was $90 \mathrm{MJ} \mathrm{ha}^{-1}$ (Mäkinen et al. 2006).

When preservatives are used in silage, the methane yield increases $17-39 \%$ compared to silage without additives (Lehtomäki 2006). In this study, AIV $2+{ }^{\circledR}$ preservative (formic acid buffered with ammonium formate; Kemira GrowHow Oyj, Espoo, Finland) was assumed to be used at a rate of $51 \mathrm{t}^{-1}$ grass. The energy input in the production of the preservative is $3.675 \mathrm{GJ} \mathrm{t}^{-1}$ and GHG emissions $3073 \mathrm{~kg} \mathrm{CO}_{2}$-eq $\mathrm{t}^{-1}$ (Grönroos and Voutilainen 2001). As a substitute for AIV $2+{ }^{\circledR}$ also a mixed microbe culture from a farm biogas reactor can be used (Lehtomäki 2006). Energy saved and GHG emissions prevented by replacing the AIV $2+{ }^{\circledR}$ with the mixed microbe culture as an ensiling additive were assessed in the sensitivity analysis.

Energy consumption of production of the grass crop, including the fuel use of machinery in ploughing, harrowing (three times per year), sowing, rolling, fertilising, liming, harvesting (three times per year), transporting and storing, is estimated at 5.53 GJ ha ${ }^{-1}$ (Palonen and Oksanen 1993).
Spreading the digestate is assumed to be carried out by a tractor and a liquid manure spreader. One tonne of silage corresponded to one tonne of digestate, because the DM loss during anaerobic digestion is insignificant, only about $58 \mathrm{~kg} \mathrm{t}^{-1}$ wet weight ley, which is the mass of the methane produced. The energy consumption of spreading the digestate is estimated at $25 \mathrm{MJ} \mathrm{t}^{-1}$ (Berglund and Börjesson 2003).

\section{Methane yield and energy demand of the biogas plant}

Methane yield of timothy-clover silage is estimated to be $0.35 \mathrm{~nm}^{3} \mathrm{CH}_{4} \mathrm{~kg}^{-1} \mathrm{DM}$ (Lehtomäki 2006), which corresponds to $12.5 \mathrm{GJ} \mathrm{t}^{-1} \mathrm{DM}$, when the lower heating value $35.7 \mathrm{MJ} \mathrm{nm}^{-3}$ for methane is used. Thus, the energy yield is $2.9 \mathrm{GJ} \mathrm{t}^{-1}$ ley (DM 23\%). Methane yield of reed canary grass is $0.38 \mathrm{~nm}^{3} \mathrm{CH}_{4}$ $\mathrm{kg}^{-1} \mathrm{DM}$, which corresponds to $13.6 \mathrm{GJ} \mathrm{t}^{-1} \mathrm{DM}$, and the energy yield is $3.93 \mathrm{GJ} \mathrm{t}^{-1}$ (DM 29\%).

The GHG emissions and energy input were determined for the operation of the farm-scale biogas plant using one-stage continuous digestion technology operating at mesophilic temperatures. A dry process was assumed, i.e. no added water. The reactor was assessed both with and without heat exchangers that use the heat of the digestate to warm the raw material. The external energy input for heating the reactor is $240 \mathrm{MJ} \mathrm{t}^{-1}$ raw materials with heat exchangers and $540 \mathrm{MJ} \mathrm{t}^{-1}$ without (Börjesson and Berglund 2007).

For pumping and mixing in the process, about $92 \mathrm{MJ}$ of electricity is needed per ton of silage (Börjesson and Berglund 2007). An external energy input is not needed if electricity is produced by combined heat and electricity production. In this study, it was assumed that the energy for heating of the reactor was taken from the biogas reactor, but electricity was taken directly from the powerdistribution network.

When biogas is used as a transport fuel, it has to be upgraded: carbon dioxide, steam and sulphur have to be removed to achieve $97 \%$ methane content. In addition, pressure has to be increased from 7 
Tuomisto, H.L. and Helenius, J. Energy and greenhouse gas balances of biogas

bars to 40 bars (Berglund and Börjesson 2003). The electricity used in the upgrading and pressurisation of the gas corresponds to an average of $5 \%$ of the energy content in the biogas produced, from which $60 \%$ corresponds to upgrading and $40 \%$ to pressurisation (Börjesson and Berglund 2006). Methane losses during the upgrading and pressurisation of the biogas varied between 0.2 and $13 \%$, but were normally under $2 \%$, and during the rest of the system the losses are minimal (Börjesson and Berglund 2006). In this life-cycle assessment, a conservative value of $2 \%$ of methane losses was assumed.

Energy inputs and GHG emissions were calculated by using the Microsoft Excel spreadsheet program. Sensitivity analyses were carried out by changing the base values in the primary data by the uncertainty range of some factors, and comparing the resulting changes in primary input/output relationships and GHG emissions/output relationships. The uncertainty ranges were based on the information provided earlier or alternatively estimated by the authors.

\section{Results}

\section{Primary energy input}

The calculated input of primary energy in the production of biogas for transport fuel use was $22-37 \%$ of the output (Fig. 2). The lowest energy input was in $\mathrm{RO} 2$, where reed canary grass was cultivated with organic fertilisers for raw material of biogas, and heat exchangers were used. The biggest energy input/output relationship (38\%) was in BL1, in which timothy-clover grass silage was used as a raw material for biogas, and heat exchanger were not used. By taking into account the energy saved by substituting mineral fertilisers by the excess digestate, the energy ratio was $33 \%$. The differences between OL and BL were basically only on the allocation methods. When the energy use from cultivating the ley was allocated to biogas, but the energy use saved by substituting mineral fertilisers was subtracted from the burden of biogas, in BL1 and BL2, the energy rations were $33 \%$ and $23 \%$, respectively, whereas when the energy used for cultivating the ley was directly allocated to the

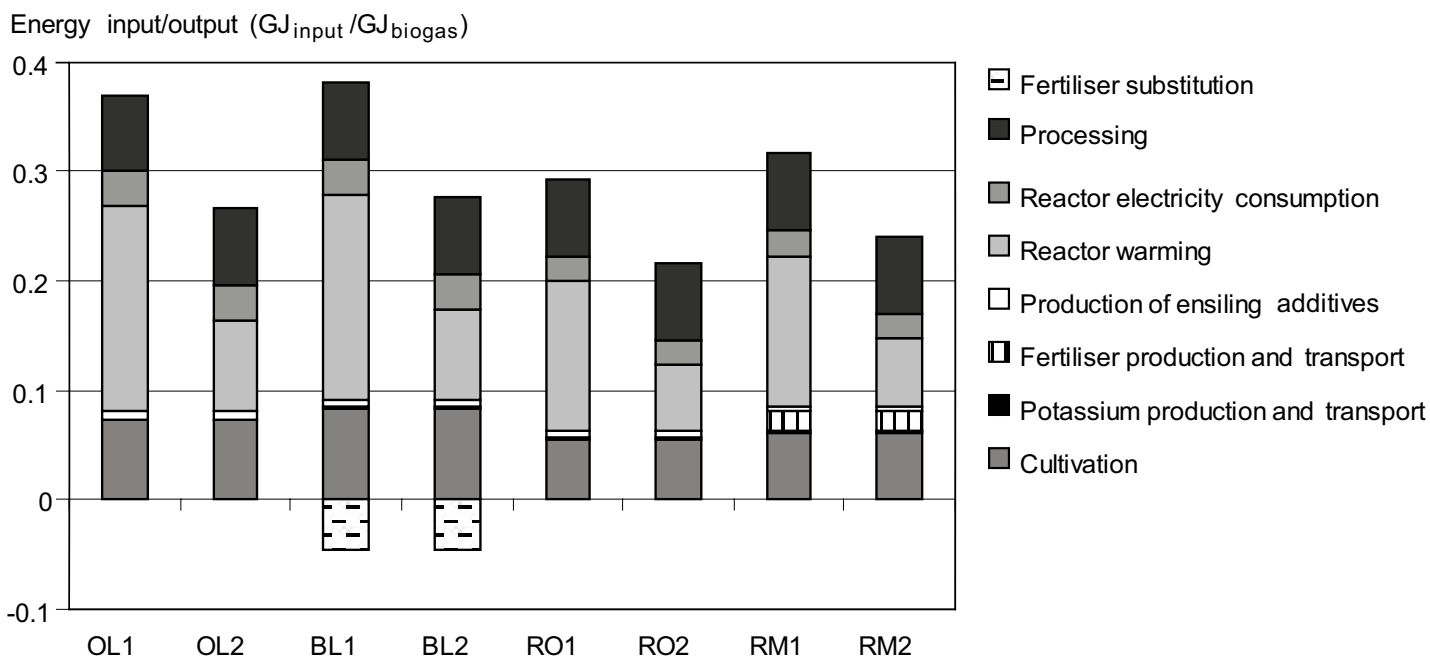

Fig. 2. Primary energy input/output relationship of biogas in the models* examined. $* \mathrm{OL}=$ organic ley, $\mathrm{BL}=$ biogas ley, $\mathrm{RO}=$ reed canary grass - organic, $\mathrm{RM}=$ reed canary grass - mineral; $1=$ heat exchangers are not used, $2=$ heat exchangers are used. 
other crops, in OL1 and OL2, the energy rations were higher, $37 \%$ and $27 \%$, respectively. In RM where mineral fertilisers were used, energy inputs were about $10 \%$ more than in RO.

The highest energy input was required for heating of the reactor, corresponding to about $49 \%$ of output without heat exchangers (1-models) and $30 \%$ with heat exchangers (2-models). Input for the production of the crops corresponded to $21 \%$ energy of output for the 1-models and $29 \%$ for the 2-models. Processing of biogas corresponded to 21 and $30 \%$ of energy output for the 1- and 2-models respectively, including methane losses. The electricity input was 8 and $12 \%$ of output for the 1 - and 2-models, respectively. Producing mineral fertilisers corresponded to about $2 \%$ energy of the output. Producing and transporting lime and producing the formic acid based ensiling additive took on average 0.5 and $1.7 \%$ of energy of the output, respectively.

\section{Greenhouse gas emissions}

The GHG emissions of biogas production were 21-35 $\mathrm{CO}_{2}$-eq $\mathrm{GJ}_{\text {biogas }}{ }^{-1}$ depending on the model (Fig 3). In the case of GHG emissions, the allocated method used for OL1 and OL2, allocated less emissions for biogas, 24 and $21 \%$ respectively, than the allocation method used for BL1 and BL2, 31 and $28 \%$ respectively. The GHG emissions were about $11 \%$ higher in RM than in RO. The fuels used in the cultivation and harvesting of ley crops contributed about $23 \%$ of the GHG emissions in biogas production. Production of ensiling additives contributed about $17 \%$ and soil $\mathrm{N}_{2} \mathrm{O}$ emissions to further about $32 \%$. Processing of biogas for transport fuel contributed about $12 \%$ of the emissions and electricity demand of the reactor about $7 \%$. In the RM, production and transport of the mineral fertilisers produced about $3 \%$ of the emissions of the system.

GHG-emissions ( $\mathrm{kg} \mathrm{CO}_{2}$-eq $\mathrm{GJ}^{-1}$ )

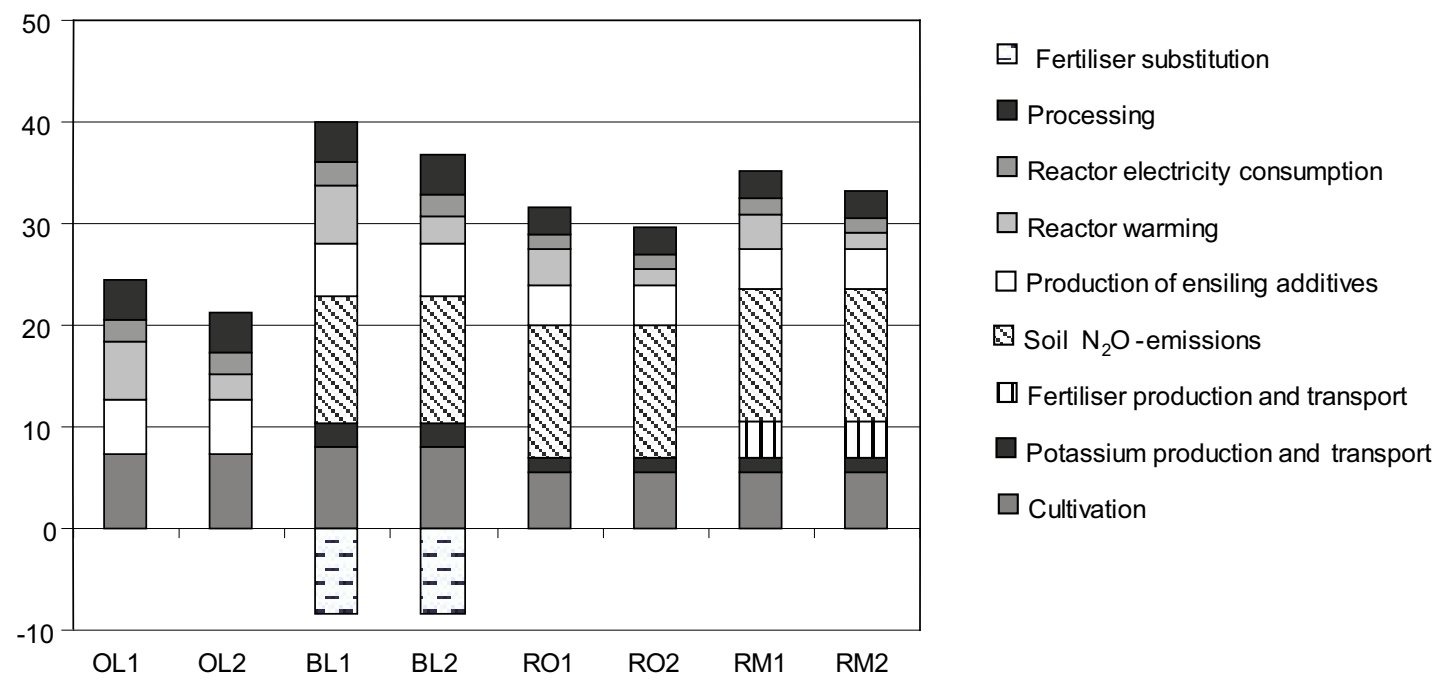

Fig. 3. Greenhouse gas emissions (GHG) of biogas in the models* examined. $* \mathrm{OL}=$ organic ley, $\mathrm{BL}=$ biogas ley, $\mathrm{RO}=$ reed canary grass - organic, $\mathrm{RM}=$ reed canary grass - mineral; $1=$ heat exchangers are not used, $2=$ heat exchangers are used. 
Tuomisto, H.L. and Helenius, J. Energy and greenhouse gas balances of biogas

\section{Energy yield and avoided GHG emissions}

The total energy yield from timothy-clover ley was $81.3 \mathrm{GJ} \mathrm{ha}^{-1}$ and from reed canary grass $122.4 \mathrm{GJ}$ $\mathrm{ha}^{-1}$. As biogas was used for heating the reactor the transport fuel yield were from timothy-clover ley 66.0 and $74.5 \mathrm{GJ}^{-1} \mathrm{~h}^{-1}$ without and with heat exchangers, respectively, and from reed canary grass 105.6 and $115.0 \mathrm{GJ}^{-1}$ without and with heat exchangers, respectively, which correspond to 45300 passenger car kilometres (fuel consumption 7 1/100 km) (Table 1). By replacing 1 GJ oil by biogas as a transport fuel GHG emissions could be reduced about $63.3-77.2 \mathrm{~kg} \mathrm{CO}_{2}$-eq $\mathrm{GJ}^{-1}$.

\section{Sensitivity analysis}

The $20 \%$ increase in the crop yield reduced the energy input by $2-4 \%$ (Table 2 ) and the GHG emissions by $3-11 \%$ (Table 3 ). The methane yield from the timothy-clover silage had a large impact both on the energy efficiency and on the GHG emissions.

Table 1. Per hectare based biogas yields, transport fuel yields (biogas yield - biogas used for reactor warming) and corresponding passenger car kilometres (fuel demand $71 / 100 \mathrm{~km}$ ), net energy yields (energy output - input) and greenhouse gas $(\mathrm{GHG})$ emissions saved by using biogas rather than fossil fuels as a transport fuel.

\begin{tabular}{|c|c|c|c|c|c|c|c|c|}
\hline Model systems* & OL1 & OL2 & BL1 & BL2 & $\mathrm{RO} 1$ & $\mathrm{RO} 2$ & RM1 & $\mathrm{RM} 2$ \\
\hline Biogas yield GJ ha-1 & 81.3 & 81.3 & 81.3 & 81.3 & 122.4 & 122.4 & 122.4 & 122.4 \\
\hline Transport fuel yield GJ ha' & 66.0 & 74.5 & 66.0 & 74.5 & 105.6 & 115.0 & 105.6 & 115.0 \\
\hline Passenger car km ha ${ }^{-1}$ & 27089 & 30570 & 27089 & 30570 & 43368 & 47189 & 43368 & 47189 \\
\hline Net energy yield GJ ha-1 & 51.2 & 59.7 & 54.1 & 62.6 & 86.6 & 95.9 & 84.2 & 93.5 \\
\hline $\begin{array}{l}\text { GHG-emission reduction } \\
\mathrm{CO}_{2} \text {-eq ha- }\end{array}$ & 4513 & 5750 & 4421 & 5224 & 7062 & 7907 & 6690 & 7502 \\
\hline
\end{tabular}

*OL= organic ley, $\mathrm{BL}=$ biogas ley, $\mathrm{RO}=$ reed canary grass - organic, $\mathrm{RM}=$ reed canary grass - mineral; $1=$ heat exchangers are not used, $2=$ heat exchangers are used

Table 2. Change (\%) in energy input/output relationship of biogas production after increasing or decreasing the parameters of the model systems.

\begin{tabular}{|c|c|c|c|c|c|c|c|c|}
\hline Model systems* & OL1 & OL2 & BL1 & BL2 & RO1 & $\mathrm{RO} 2$ & RM1 & RM2 \\
\hline Crop yield $+20 \%$ & -2.0 & -2.8 & -1.9 & -2.7 & -2.0 & -2.7 & -3.0 & -3.9 \\
\hline Methane yield $-10 \%$ & 9.0 & 8.2 & 8.8 & 7.7 & 8.5 & 7.5 & 8.7 & 7.9 \\
\hline Machinery fuel consumption $+28 \%$ & 5.6 & 7.8 & 6.9 & 10.0 & 5.4 & 7.2 & 5.4 & 7.1 \\
\hline Reactor warming $-20 \%$ & -10.1 & -6.3 & -11.2 & -7.3 & -9.4 & -5.6 & -8.7 & -5.1 \\
\hline Reactor electricity consumption $-20 \%$ & -1.7 & -2.4 & -1.9 & -2.8 & -1.6 & -2.2 & -1.5 & -1.9 \\
\hline Processing $+20 \%$ & 3.8 & 5.3 & 4.2 & 6.1 & 4.8 & 6.5 & 4.4 & 5.8 \\
\hline Mixed culture as ensiling additive & -1.7 & -2.4 & -1.9 & -2.8 & -1.6 & -2.2 & -1.5 & -1.9 \\
\hline No ensiling additive + methane yield $-20 \%$ & 18.1 & 15.4 & 17.4 & 13.9 & 17.0 & 14.2 & 17.7 & 15.4 \\
\hline
\end{tabular}

$* \mathrm{OL}=$ organic ley, $\mathrm{BL}=$ biogas ley, $\mathrm{RO}=$ reed canary grass - organic, $\mathrm{RM}=$ reed canary grass - mineral; $1=$ heat exchangers are not used, $2=$ heat exchangers are used 
Vol. 17 (2008): 240-251.

Table 3. Change (\%) in greenhouse gas emissions of biogas production after increasing or decreasing the parameters of the model systems.

\begin{tabular}{|c|c|c|c|c|c|c|c|c|}
\hline Model systems* & OL1 & OL2 & BL1 & BL2 & RO1 & $\mathrm{RO} 2$ & RM1 & RM2 \\
\hline Crop yield $+20 \%$ & -5.6 & -4.8 & -10.8 & -10.7 & -2.8 & -2.8 & -4.3 & -4.4 \\
\hline Methane yield $-10 \%$ & 12.2 & 10.5 & 12.0 & 10.7 & 11.5 & 10.7 & 11.5 & 10.8 \\
\hline Soil $\mathrm{N}_{2} \mathrm{O}$-emissions $+338 \%$ & 0.0 & 0.0 & 133.7 & 148.6 & 139.8 & 148.9 & 125.8 & 133.1 \\
\hline Soil $\mathrm{N}_{2} \mathrm{O}$-emissions $-84 \%$ & 0.0 & 0.0 & -33.2 & -36.9 & -34.7 & -37.0 & -31.3 & -33.1 \\
\hline Machinery fuel consumption $+28 \%$ & 8.3 & 9.6 & 7.2 & 8.0 & 4.9 & 5.2 & 4.4 & 4.7 \\
\hline Reactor warming $-20 \%$ & -4.7 & -2.4 & -3.6 & -1.8 & -2.2 & -1.0 & -2.0 & -0.9 \\
\hline Reactor electricity consumption $-20 \%$ & -1.8 & -2.1 & -1.4 & -1.6 & -0.9 & -1.0 & -0.8 & -0.9 \\
\hline Processing $+20 \%$ & 3.2 & 3.7 & 2.5 & 2.7 & 1.7 & 1.8 & 1.5 & 1.6 \\
\hline Mixed culture as ensiling additive & -21.9 & -25.1 & -17.0 & -18.9 & -12.3 & -13.1 & -11.1 & -11.7 \\
\hline No ensiling additive + methane yield $-20 \%$ & 1.0 & -7.3 & 6.3 & 0.8 & 10.9 & 7.9 & 12.3 & 9.7 \\
\hline
\end{tabular}

$* \mathrm{OL}=$ organic ley, $\mathrm{BL}=$ biogas ley, $\mathrm{RO}=$ reed canary grass - organic, $\mathrm{RM}=$ reed canary grass - mineral; $1=$ heat exchangers are not used, $2=$ heat exchangers are used

When methane potential of the silage was decreased by $10 \%$, the energy input increased by $8-9 \%$ and GHG emissions $11-12 \%$. When AIV $2+{ }^{\circledR}$ ensiling additive was substituted by mixed microbe culture from the biogas reactor, the energy input decreased about $2 \%$, and the GHG emissions decreased about $16 \%$. If ensiling additives were not used at all and methane yield was assumed to consequently decrease by $20 \%$, the energy input ratio increased $14-18 \%$, whereas the GHG emissions increased by $6-12 \%$ in the most of the models.

By improving the reactor technique so that the energy input for reactor warming (for a GJ of methane produced) required was $20 \%$ lower, the energy input ratio of biogas decreased about $5-11 \%$ depending on the model system. The impact of manufacturing and maintaining machinery was not included in the base data, but it was simulated in the sensitivity analysis by increasing the consumption of fuel by $28 \%$. This increased the energy input of biogas production by $5-10 \%$ and GHG emissions by $4-10 \%$.

The highest uncertainty of the systems is in the $\mathrm{N}_{2} \mathrm{O}$ emissions due to their large uncertainty range.
By using the IPCC lowest and highest uncertainty factors for $\mathrm{N}_{2} \mathrm{O}$ the total $\mathrm{GHG}$ emissions of the systems decreased by $34 \%$ and increased by $138 \%$, respectively.

\section{Discussion}

Calculated energy input and GHG emissions per unit of energy produced were much lower for biogas than for bioethanol and biodiesel when all were used as transport fuel (Fig. 4). The efficiencies were calculated for domestic agricultural biomassbased production in Finland, where the growing season is short and crop yield levels lower than in most other industrialised countries. As the energy efficiency was not sensitive to yield level, the GHG balance alone may show a reduced relative benefit from biogas production in regions of higher yield levels. The GHG emissions from field-based biogas were about $21-36 \%$ those from fossil petrol or diesel (Fig 4). When manure or biowaste from 
Tuomisto, H.L. and Helenius, J. Energy and greenhouse gas balances of biogas

Fig. 4. Comparison of greenhouse gas emissions (GHG) of organic ley 2 (OL2) and reed canary grass -organic 2 (RO2) -models with some transport fuel options. (Petrol/diesel, barley ethanol and rape methyl ester (RME) from Mäkinen et al. (2006), biogas/manure, community waste and food industry waste from Berglund \& Börjesson (2007)).

food industry or from the community was used to produce the biogas, the GHG emissions were only about $13-23 \%$ of those from fossil fuels (Berglund and Börjesson 2007).

In the models studied, the energy inputs were lowest in the reed canary grass models (RO and $\mathrm{RM})$ due to the greater yields compared with timothy-clover. However, the GHG emissions were lower in the timothy-clover ley (OL and BL) models, because these systems produce fertilisers as a co-product, which reduces the GHG emission burden of biogas. The allocation method chosen in OL, in which energy inputs and GHG emissions of cultivation were not included in the burden of biogas, resulted in higher energy input, but lower level of GHG emissions than in BL, in which all inputs and emissions were allocated to biogas, but the energy and emissions saved by substituting mineral fertilisers by digestate were subtracted from the burden of biogas. One can argue that in OL some of the inputs and emissions should be allocated to biogas too. In this study, however, it was assumed that the ley would have been cultivated anyway for green manure, and therefore biogas production was regarded only as an improvement of the system. Furthermore, the BL was developed in order to provide a comparative allocation approach.

The use of mineral fertilisers increased the energy input of biogas by $11 \%$ and GHG emissions by $8 \%$, when RM and RO were compared. However, in the both systems the digestate was used as a fertiliser, but mineral fertilisers were used only as an additional fertiliser in the RM.

The high energy and GHG costs of the AIV $2+{ }^{\circledR}$ industrial ensiling agent are worth noting. When a mixed microbial culture, available from the biogas reactor, was used such costs were avoided. On the other hand, handling costs of the silage may be increased in case the silage becomes partially liquidised by the microbes: more technological research is needed to solve such issues. Furthermore, the optimising of the amount of mixed culture has a significant impact on the methane yield.

The energy input of biogas production could be reduced by developing reactor technology, and by using crops that have a high potential yield of 
Vol. 17 (2008): 240-251.

methane. In addition, reducing the consumption of fossil fuels in machinery could reduce GHG emissions. In this study, it was assumed that farm machinery used fossil fuels.

The results of energy input and GHG emissions presented in this paper differ somewhat from previous study of Berglund and Börjesson (2006). In their calculations, the energy input of biogas was about $50 \%$ of output, whereas in this paper it was only $22-37 \%$. Contributing reasons are that Berglund and Börjesson (2006) used mineral fertilisers for grass and they included the production and service of machinery in their calculations. Fredriksson et al. (2006) calculated the energy input for biogas to be about $21 \%$ of output when the green manure of an organic farm was used as a raw material, whereas in this paper the OL gave $27 \%$ with heat exchangers and $37 \%$ without. Fredriksson et al. (2006) did not report whether heat exchangers were used, but their low energy consumption figure suggests the use of heat exchanger. Thus, this study supports the results of Fredriksson et al. (2006); the relatively small differences are due to small differences in the input data.

In the case of GHG emissions, there are not quite comparable data available, because Berglund and Börjesson (2006) included carbon dioxide emissions only. If only carbon dioxide emissions are compared, the emissions reported in this paper are still greater due to the big emissions due to the production of ensiling additive. However, Berglund and Börjesson (2006) did not identify what kind of ensiling system they used.

\section{Reliability and uncertainty of the results}

Because the data were based on literature values, and real field studies were not carried out, the results are only indicative. The results are directly comparable with those of Mäkinen et al. (2006) on energy and GHG balances of bioethanol and biodiesel, because the initial input data and assumptions were similar.

The systems were quite sensitive to some key factors. The most significant factor for energy ef- ficiency was the methane yield, which is affected by the crop used and timing of harvesting. If harvesting time is not carefully optimised, the methane yield can be significantly lower resulting in lowered efficiency (Lehtomäki 2006). In addition, reactor technology and the process used had a significant impact on the energy input.

For GHG emissions the most significant uncertainties remained in soil $\mathrm{N}_{2} \mathrm{O}$ emissions. These emissions have been found to be lower for anaerobically digested than for undigested manure (Petersen 1999). Data for $\mathrm{N}_{2} \mathrm{O}$ emissions of anaerobically treated crop biomass was lacking, and thus, in this study default factors were used.

\section{Conclusions}

Biogas production in agriculture provides an energy- and GHG-efficient option for biofuel production. The efficiency of agricultural bioethanol has recently been debated. Although there are uncertainties among some of the parameters, it is obvious that biogas performs better than either ethanol or biodiesel.

In order to achieve the best energy and GHG balances it is desirable to use transport fuels derived from renewable crop harvest, organic wastes, or residues from agriculture, food industry, and communities. Biogas offers a flexible technology, because any digestible organic material can be used as a raw material.

Production of biogas can also be linked to recycling of nutrients from communities back to the fields if community waste or sewage sludge is used as raw materials for biogas. In addition, crops from marginal lands, such as field edges or road verges, and harvests of aquatic plants from sedimentation pools etc. can be used in biogas production. Such harvesting could give additional environmental benefits by supporting diversity of species, which are dependent on grazing or cutting, and by removing excess nutrients from the source habitats. Furthermore, the harvesting of ley in organic crop rotations can reduce nitrogen leaching 
Tuomisto, H.L. and Helenius, J. Energy and greenhouse gas balances of biogas

and $\mathrm{N}_{2} \mathrm{O}$ emissions, because the nitrogen can be applied at the time when the crops' nutrient intake is the highest.

Replacement of fossil fuels in the transport sector is extremely challenging. Even though it is more efficient, in terms of $\mathrm{CO}_{2}$ emissions, to use biomass to replace fossil fuels in production of combined heat and power than in production of transport fuels, it is still important to develop technologies for reducing the use of fossil fuels in the transport sector. Thus, the use of biogas as transport fuel is a noteworthy option worth further study.

When biofuel options are considered it is important to carefully assess the environmental aspects, because biofuels are not always the best option for the environment. Even if biofuels are produced, the targets to reduce the total energy consumption in transportation sector are also essential.

Acknowledgements The study was funded by Ministry of Agriculture and Forestry, Finland and Tritonet Ltd, Tampere, Finland. We are very grateful to managing director Pertti Keskitalo (Tritonet Ltd) as well as Head of Unit Taina Vesanto, Senior Advisor Elina Nikkola and Senior Advisor Veli-Pekka Reskola (Ministry of Agriculture and Forestry, Finland), as well as to researcher Tuula Mäkinen (VTT Technical Research Centre of Finland) and researcher Annimari Lehtomäki (Jyväskylä Innovation Ltd) for their valuable information, and to many people for their critical comments, including professor Jukka Ahokas, Jukka Kivelä, Tuomas Mattila (all from University of Helsinki) and Marko Sinkkonen (MTT Agrifood Research Finland), and to Fred Stoddard (University of Helsinki) and Mervyn Tucker (University of Bangor) for comments and linguistic revision.

\section{References}

Berglund, M. \& Börjesson, P. 2003. Energianalys av biogassystem. Lunds tekniska högskola. Lunds universitet. Institution för teknis och samhälle. Avdelningen för miljöoch energisystem. Rapport nr 44. Maj 2003. 89 s. Cited 20 June 2006. Available on the Internet: http://www.miljo. Iht.se/svenska/internt/publikationer_internt/pdf-filer/Energianalys $\% 20$ av\%20biogassystem\%2044.pdf

Berglund, M. \& Börjesson, P. 2006. Assessment of energy performance in the life-cycle of biogas production. Biomass and Bioenergy:30 254-266.

Börjesson, P. \& Berglund, M. 2006. Environmental systems analysis of biogas systems - Part I: Fuel-cycle emissions. Biomass and Bioenergy 30:469-485.

Börjesson, P. \& Berglund, M. 2007. Environmental systems analysis of biogas systems - Part II: The environmental impact of replacing various reference systems. Biomass and Bioenergy 31:326-344.

Directive 2003/30 EC of the European Parliament and of the Council of 8 May 2003 on the promotion of the use of biofuels or other renewable fuels for transport. Cited 10 May 2006. Available on the Internet: http://ec.europa. eu/energy/res/legislation/doc/biofuels/en_final.pdf

Edwards, R., Griesemann, J-C., Larivé, J-F. \& Mahieu, V. 2003. Well-to-Wheels Analysis of Future automotive and Powertrains in the European Context. Jointly carried out by EUCAR, CONCAWE and JRC/IEA. Tankto-Wheels Report Version 1, December 2003. Cited 20 May 2006. Available on the Internet: http://ies.jrc.cec. eu.int/wtw.html.

Fredriksson, H., Baky, A., Sernesson, S., Nordberg, Å., Norén, O. \& Hansson, P.-A. 2006. Use of on-farm produced biofuels on organic farms - Evaluation of energy balances and environmental loads for three possible fuels. Agricultural Systems 89:184-203.

Grönroos, J. \& Voutilainen, P. 2001. Maatalouden tuotantotavat ja ympäristö - Inventaarioanalyysin tulokset. Suomen ympäristökeskus 231. Helsinki. Cited 14 June 2006. Available on the Internet: http://www.ymparisto. fi/download.asp?contentid=15182\&lan=FI

IPCC 1996. Climate Change 1995. The Science on Climate Change. Contribution of Working Group I to the Second Assessment Report of the Intergovernmental Panel on Climate Change. Great Britain. 572 s.

Jungmeier, G. \& Spitzer, J. 2001. Greenhouse gas emissions of bioenergy from agriculture compared to fossil energy for heat and electricity supply. Nutrient Cycling in Agroecosystems 60:267-273.

Kangas, A., Laine, A., Niskanen, M., Salo, Y., Vuorinen, M., Jauhiainen, L. \& Nikander, H. 2006. Virallisten lajikekokeiden tulokset 1998-2005. MTT:n selvityksiä 105. Cited 10 June 2006. Available on the Internet: http://www. mtt.fi/mtts/pdf/mtts105.pdf

Kangas, A., Laine, A., Niskanen, M., Salo, Y., Vuorinen, M., Jauhiainen, L. \& Nikander, H. 2004. Virallisten lajikekokeiden tulokset 1996-2003 MTT:n selvityksiä 55. Available on the Internet: http://www.mtt.fi/mtts/pdf/ mtts55.pdf

Lehtomäki, A. 2006. Biogas production from energy crops and crop residues. Jyväskylä studies in biological and environmental sciences 163. Jyväskylän yliopisto. Cited 15 June 2007. Available on the Internet: http://dissertations.jyu.fi/studbiol/9513925595.pdf

Mäkinen, T., Soimakallio, S., Paappanen, T., Pahkala, K. \& Mikkola, H. 2006. Liikenteen biopolttoaineiden ja peltoenergian kasvihuonekaasutaseet ja uudet liiketoimintakonseptit. VTT Tiedotteita. 141 s. + 18 liitettä. Cited December 2006. Available on the Internet: http://www.vtt. fi/inf/pdf/tiedotteet/2006/T2357.pdf

Palonen, J. \& Oksanen, E. 1993. Labour, machinery and energy data bases in plant production. Työtehoseuran julkaisuja 330. Helsinki.

Petersen S. 1999. Nitrous oxide emissions from manure and inorganic fertilisers applied to spring barley. Journal of Environmental Quality 28:1610-1618. 


\title{
SELOSTUS
}

\section{Peltobiokaasu liikenteen biopolttoainevaihtoehtona energia- ja kasvihuonekaasutaseiden kannalta}

\author{
Hanna L. Tuomisto ja Juha Helenius \\ Helsingin yliopisto
}

Tutkimuksen tavoitteena oli verrata peltobiokaasun energia- ja kasvihuonekaasutaseita muihin kotimaisiin liikenteen biopolttoainevaihtoehtoihin. Peltobiokaasun elinkaariset kasvihuonekaasupäästöt ja energiatase laskettiin, kun raaka-aineena oletettiin käytettävän timotei-apilanurmi- ja ruokohelpisäilörehua. Yhtenä vaihtoehtona tarkasteltiin luomukasvintuotantotilan viherlannoitusalan käyttöä biokaasun raaka-aineena. Lisäksi tutkittiin lannoitevalintojen vaikutuksia taseisiin.

Biokaasun energiapanos ja kasvihuonekaasupäästöt olivat pienemmät kuin ohraetanolilla ja rypsibiodieselillä. Energiapanoksen suuruus peltobiokaasulla oli raakaaineesta riippuen noin $22-37 \%$ tuotoksesta, kun taas kotimaisen ohraetanolin energiapanoksen on arvioitu olevan $82 \%$ ja rypsibiodieselin $50 \%$ tuotoksesta. Kasvihuonekaasupäästöt ohraetanolilla ja rypsibiodieselillä on arvioitu jopa ylittävän fossiilisten polttoaineiden päästöt, kun taas peltobiokaasun elinkaaren aikaiset kasvihuonekaasupäästöt olivat vain noin $21-36 \%$ fossilisten polttoaineiden päästöistä. Lannasta, elintarviketeollisuuden jätteistä ja orgaanisesta yhdyskuntajätteestä valmistetun biokaasun kasvihuonekaasupäästöjen on arvioitu olevan noin $13-23 \%$ fossiilisten polttoaineiden kasvihuonekaasupäästöistä.

Suurin energiapanos vaadittiin biokaasureaktorin lämmityksessä, kun taas kasvihuonekaasupäästöistä suurin osa syntyi viljelyssä. Peltobiokaasun tuotannossa suurimmat kasvihuonekaasupäästölähteet olivat työkoneiden polttoaineiden päästöt, maan dityppioksidipäästöt sekä biomassan säilöntään käytetyn rehunsäilöntäaineen valmistuksen päästöt. Säilöntäaine tosin voidaan korvata reaktorin mikrobisiirroksella.

Energia-, kasvihuonekaasu- sekä ravinnetaseiden kannalta olisi kannattavinta käyttää bioenergian raakaaineena ensisijaisesti maatalouden, elintarviketeollisuuden ja yhdyskuntien orgaanisia jätteitä ja sivutuotteita. Biokaasuteknologia tarjoaa tähän erinomaisen mahdollisuuden, sillä biokaasua voidaan valmistaa kaikesta orgaanisesta aineksesta. Lisäksi biokaasuteknologia mahdollistaa ravinteiden tehokkaan kierrätyksen, sillä biokaasutusjäännös on erinomaista lannoitetta. 